\title{
DEVELOPMENT OF THE REQUIRED TOPOGRAPHIC DATA FOR AN EFFECTIVE IRRIGATION SCHEME, USING SPACE TECHNOLOGIES CASE STUDY: NORTH OMDURMAN RURAL AREAS
}

\author{
Gar Alnabi, Ibrahim Mohamed'; Al-tayeb, Yahya Hasan² \\ 1 University of Khartoum, faculty of Engineering, Sudan \\ gar_ibrahim@yahoo.com \\ 2 Remote Sensing Authority, Sudan
}

\begin{abstract}
Considering the growing negative environmental impacts all over the world and the deteriorating living standards in Sudan, this paper focuses on the authors' contribution to an agricultural project that aims at participating in solving such problems in the study area. The study area, which is exploited by the local farmers, is located north of Omdurman at the western bank of the River Nile.

The main objective of the entire project is to establish an irrigation scheme that provides cheaper, sufficient and constant water supply in order to reduce the irrigation cost and effort and increase productivity, leading to reducing the poverty level and improving the living standards.

The contribution of the authors in this project is represented in the provision of the basic topographic information which represents a decisive factor for the design of the proposed irrigation scheme. The data used for getting the topographic information were space technology data such as Real time GPS readings, GPS Navigator readings, and Landsat ETM + image, as well as, digital ground survey data such as readings taken by the Total Station survey instrument at site.

Using ERDAS Imagine 8.5, the ETM+ image was processed, interpreted to extract the necessary planimetric information. Using ArcGIS9.3 - Geostatistical Analyst, the GPS and Total Station readings were processed to obtain detailed information about the terrain.

The effort made by the authors clearly revealed the important role of space technology to conduct the studies that assist in designing projects that reduce the negative environmental impacts and improving the living standards in the project area. The integration of the GIS facilities with this data represents an excellent addition, because it facilitates the presentation of the output in the form of dynamic maps accompanied by attributes of the different layers, beside the static maps. These layers are very useful for designing the detailed engineering activities required for designing the required irrigation scheme in a later stage.
\end{abstract}

Keywords: Irrigation Scheme, Rural Areas, Space Technology 


\section{INTRODUCTION}

\subsection{BACKGROUND}

Sudan's oil production began in the late 1990s and grew rapidly starting in July 1999 with the completion of an export pipeline that runs from South Sudan through the North to the Port of Sudan. Sudan produced an estimated 401,000 barrels per day (b/d) in 2005 , which brought in about $\$ 1.9$ billion and provided $70 \%$ of the country's total export earnings. As of 2007, oil production in Sudan was at 466,100 barrels per day. In 2010, oil accounted for over $90 \%$ of Sudan's foreign exchange earnings. Prior to South Sudan's July 2011 secession, roughly $75 \%$ of Sudan's oil production, representing almost $36 \%$ of government revenues, came from fields located in the South. Remaining production in Sudan barely covers domestic use [1].

The July 2011 secession of South Sudan had an immediate and profound impact on Sudan's economy, and the reverberations from the split will continue to resound in the coming years. While the composition of what the "new" Sudanese economy will be is unclear, the country will not be able to rely on the oil production and export that had served as the principal driver of growth since 2000 . With much of its oil production having come from what is now South Sudan; Sudan has suffered a dramatic decline in its oil revenues. The government has targeted agriculture, mining, and enhanced oil production as sectors for development [1].

Meeting the Millennium Development Goal on hunger will mean doubling food production by 2050 . Food insecurity is one of the major challenges facing the world; therefore every country should make much effort to increase its production especially in the agricultural field. Agriculture remains the largest employment sector in most developing countries.

The agricultural sector is the core of Sudan life and the main driving force for its economy even with the emerging oil sector. Sudanese economy is predominately agricultural with $70 \%$ of the population deriving their livelihoods in rural areas. Agriculture contributes $46 \%$ of the country's Gross Domestic Production (GDP) and more than $90 \%$ of the non-oil export earnings. In addition, it accounts for about two thirds of the employment and supplies about $60 \%$ of the raw material needed by the manufacturing sector [2].

In Sudan, agriculture, which was the economy's mainstay prior to oil, accounted for about a third of the GDP prior to secession. It represented 90\% of Sudan's 2009 non-oil exports, and the sector employed about $80 \%$ of the labor force. Sudan's authorities are looking at increasing agricultural production in an effort to diversify growth; only an estimated 15\%-20\% of Sudan's arable land is cultivated. The authorities have launched an Agricultural Revitalization Plan to invest some $\$ 5$ billion in the sector through 2012, and hoped to attract strategic foreign investors. However, Sudan remains a net importer of food. Problems of irrigation and transportation remain the greatest constraints to a more dynamic agricultural economy $[1,3]$.

Gadkarim reported that the first economic variable that petroleum started to influence to consider is the GDP [3]. As shown in Fig.1. , before 1999 and even in 1999, the year which witnessed the beginning of Sudanese exports of oil, the petroleum sector contribution to the GDP was negligible. Prior to that date, the shortage of petroleum products was a permanent handicap impeding the economy's 
development with all its negative implications especially on production and growth.

Figure 1 clearly illustrates three trends in the composition of the GDP, namely: a) an increasing contribution of the oil sector to the GDP from 2\% in 1999 to $21 \%$ in 2007 and to an average of $9 \%$ afterwards, b) a declining significance of the agricultural sector from half the GDP in 1999 to about 31\% in 2010, and c) there was no or only a slight change in the other sectors' (the services, building, construction, electricity and water) contributions, other than services taking over the lead after the deterioration of oil revenue after 2008 [4].

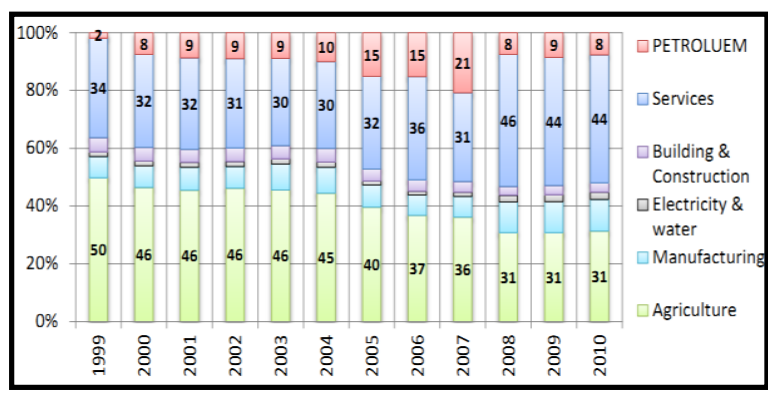

Fig.1. Trend of Sudan GDP from 1999 to 2010 Source: Central Bank of Sudan (CBoS)

The calamities of Sudan expand on a daily basis. The secession of Southern Sudan has deprived the country of $25 \%$ of its total area, $24 \%$ of its population, over $80 \%$ of its oil income. Moreover, Southern Sudan has separated with $75 \%$ of vegetation cover and $30 \%$ of potential arable land.

In the study area, the farmers use small water pumps for irrigation from the River Nile. This method of irrigation is very costly, time consuming, has negative environmental impacts, and it does not provide sufficient and constant water supply for the farms, leading to lower productivity and income and consequently more poverty. One of its negative environmental impacts is the pollution resulting from oil spills and exhaust fumes.
This background manifests the necessity for the Sudan to rely on agriculture as a major source of foreign exchange and government revenue. The agricultural sector also should represent a growing contributor to the GDP. Based on the above information, the importance of the agricultural sector to the social and political stability, economic growth and prosperity, ..etc of Sudan cannot be overemphasized, therefore, it is of utmost necessity to solve the problems that encounter the agricultural sector in Sudan. One of these problems is the irrigation which will be considered in this paper for the study area from the topographic point of view. The other aspects of designing the irrigation system are beyond the scope of this paper.

This paper presents the contribution of the authors in a multi-stakeholders project that aims at improving the peoples' standards of living and reducing the environmental negative impacts in the study area. This project was sponsored by the Ministry of Agriculture, Khartoum State, Sudan. The contribution of the authors in this project was represented by the provision of the basic topographic data required for the establishment of a cost effective and environmentally friendly modern irrigation scheme. This topographic data is derived from space technology data and digital ground survey data. The space technology data is composed of Real time GPS data; land sat $\mathrm{ETM}+$ data, and GPS Navigator data. The digital ground survey data is composed of site readings taken by the total station survey equipment.

\subsection{THE STUDY AREA}

The project area is located north of Omdurman, at the Western River Nile bank. It is bounded by the River Nile in the east and a strip of scattered villages, rock out-crops, hills and a number of valleys running towards 


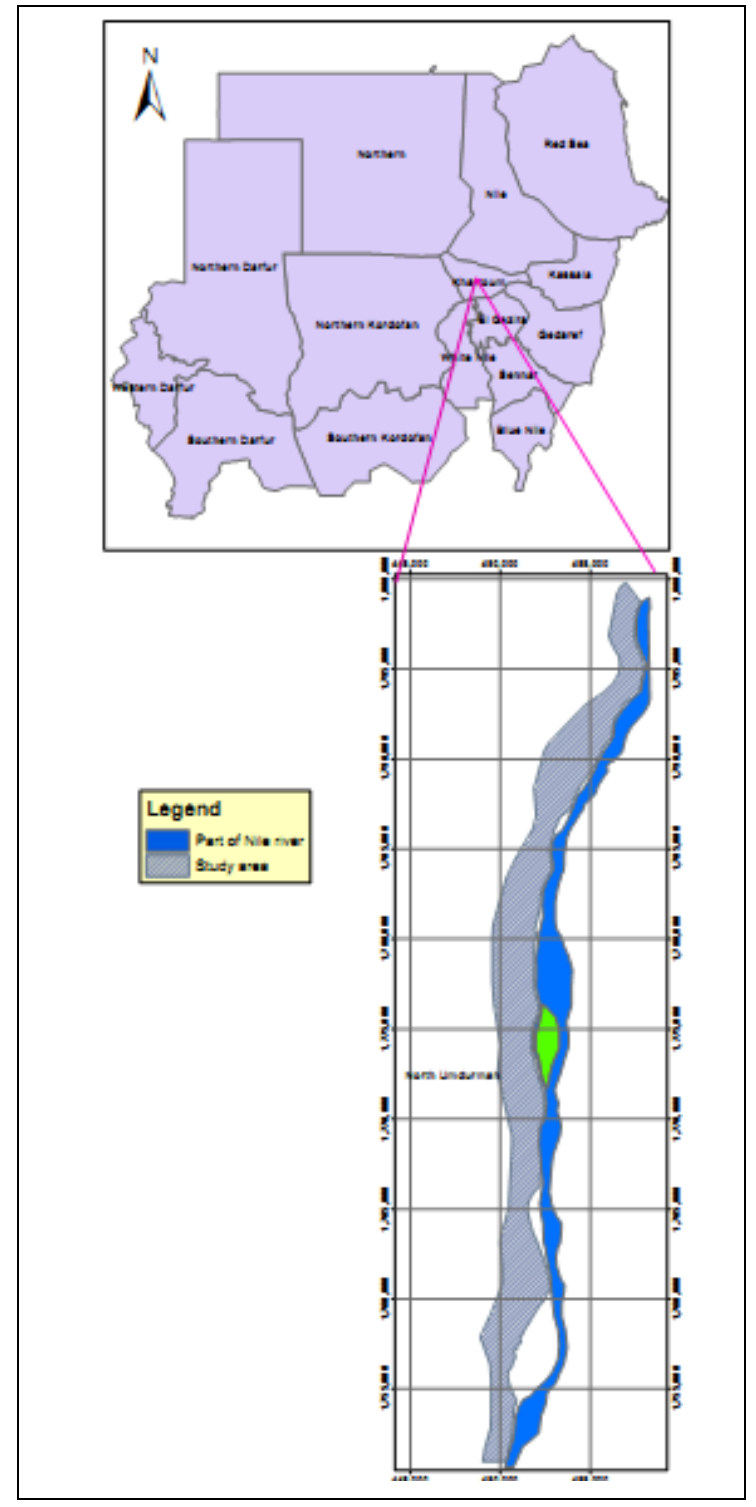

Fig.2. Location of the study area

the River Nile. The width of the area in the east- west direction ranges between $400 \mathrm{~m}-$ $2,000 \mathrm{~m}$, but the length in the north-south direction is $48 \mathrm{~km}$. The total project area is 9,446 feddan (3967 ha). Figure 2 shows the general location of the study area.

\subsection{THE RESEARCH PROBLEM}

The method of irrigation (using small individual pumps) is, of course, very costly, time consuming, has negative environmental impacts and above all it does not provide sufficient water supply for the farms. Moreover, the River Nile water level

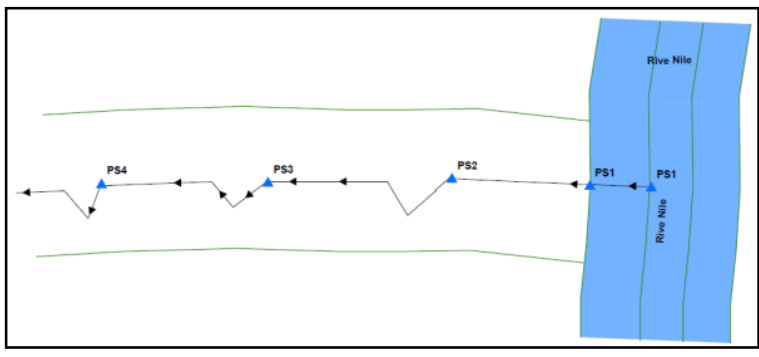

Fig.3. Using multiple pumping machines or using more than one machine for the same farm

fluctuates during the year. It is low during summer and high during the rainy season. This situation forces the farmers to move their pumping machines from time to time or to use more than one machine for the same farm, according to the water level. When the water level is low, the distance between the machines locations and the farms becomes longer and consequently the operation costs become higher (more fuel and spare parts consumption). The negative impacts of this method of irrigation are more environmental hazards (spilling of fuel, emission of fumes,...etc), lower productivity and income leading to more poverty in the area, Figure 3 shows how the farmers suffer since they keep shifting their pumps all over the year.

As mentioned above the existing scheme is composed of small water pumping machines randomly scattered in the project area. Most of these machines are operated with fuel and very few of them are using electricity (in areas of large cities). The number of these machines depends on the actual number of Sagias and land divisions in the area. The Sagia is the registration land unit and the land division is the amount of land owned by each inheritor of these Sagias as shown in Table 1.

TABLE 1: DETAILS OF SAGIAS IN THE PROJECT AREA

\begin{tabular}{|c|c|c|c|}
\hline Section & No.of Sagias & Area (Feddan) & No. of villages \\
\hline Gamuia & 119 & 2930 & 6 \\
\hline Gimaiab & 95 & 4656 & 12 \\
\hline Shaiqia & 43 & 1860 & 6 \\
\hline Total & 256 & 9446 & 24 \\
\hline
\end{tabular}


Table 1, reveals a total number of 256 Sagias in the project area. So if one assumes that there is an average of 5 inheritors of each Sagia. This results in a total of 1,280 land divisions (one land division for each inheritor) in the project. This would give a minimum of 1,280 pumping machines in the project area. Also, it should be mentioned that some of the farmers are forced to use more than one pumping machine, especially for the land divisions extending in the east west direction (the western edge is farther from the River Nile). Also, sometimes, the owner of the land division may rent it to a group of people, and they may or may not share one pumping machine. Accordingly, each land division may be irrigated by a number of pumping machines, depending on its actual area and the number of farmers using it. This clearly, revealed that the actual number of the pumping machines in this system is much larger than the one estimated at the beginning of this paragraph.

Hence, there is a negative environmental impact of the existing irrigation scheme. A minimum of 1,280 small water pumping machines scattered over an area of 9,446 feddan $(3,822 \mathrm{ha})$, with an average of one machine for each 7.38 feddans. There is no doubt that, the disposals of these machines, such as, the exhaust fuel smoke, machines noise, the consumed spare parts, the spilling fuel,...etc, will have a very damaging environmental effect in the project area.

\subsection{THE RESEARCH OBJECTIVE}

The main objective of the research is, therefore, to provide the topographic data that is required to design (in a subsequent stage) an irrigation scheme with cheaper and more constant water supply for the farms in order to reduce the irrigation cost and efforts and the negative environmental impacts. This will reduce the poverty level and, hence, improve the standards of living in the area.

\section{METHODOLOGY}

\subsection{THE MATERIALS AND TOOLS:}

The project topographic data is derived from an integration of space technology data, and digital ground survey data. The space technology data is composed of Real time GPS data, GPS navigator data; and Land sat $\mathrm{ETM}+$ data.

The Real Time GPS data was collected using dual frequency real time GPS and was used to tie the project with the Sudan National grids and to control the digital ground survey data at the locations of the irrigation scheme's proposed pumping stations.

The GPS Navigator was used to plan and direct all the digital ground survey data activities in the project area.

The Landsat ETM + data was used to digitize the main feature such as the River Nile, Villages,...etc. This dataset was downloaded from the free of charge internet data sources.

The digital ground survey data was collected using the total station equipment and was used for mapping the topography (contours) and the details of the project area (villages, valleys, electric lines, crude oil line, etc) as a double check for the features digitized from the Landsat dataset.

\subsection{ThE METHOD:}

The project data shown in the flow chart of Fig.4. was processed using the GIS mapping facilities available in ArcGIS9.3 application program and its supporting extensions:

1. GPS and total station data were processed using the 3D Analyst Toolbar to obtain the Triangulated Irregular Network (TIN) using the tool: [3D Analyst Toolbar--Create/Modify TIN--- Create TIN From Feature]. 
2. Using the $3 \mathrm{D}$ Analyst Toolbar with the TIN to generate the longitudinal profiles along the routes of the proposed canals, based on the elevation values stored in the TIN dataset cells, the tools is: [3D Analyst Toolbar --- the Icon: "Interpolate line" to trace the proposed route of the canal, then ---- the Icon: "Create Profile Graph"].

3. Again the TIN is used with the [Geostatistical Analyst Toolbar -.Geostatistical Wizard] to create contour lines of the study area using also the elevation values stored in the TIN dataset cells.

4. ArcMap was used for digitizing the main features (River Nile, islands,...etc), compiling, layout and presenting the project data.

5. Typical supporting programs which were used included, ERDAS Imagine 8.5 for processing the landsat data (layer staking, enhancement, ...etc)..

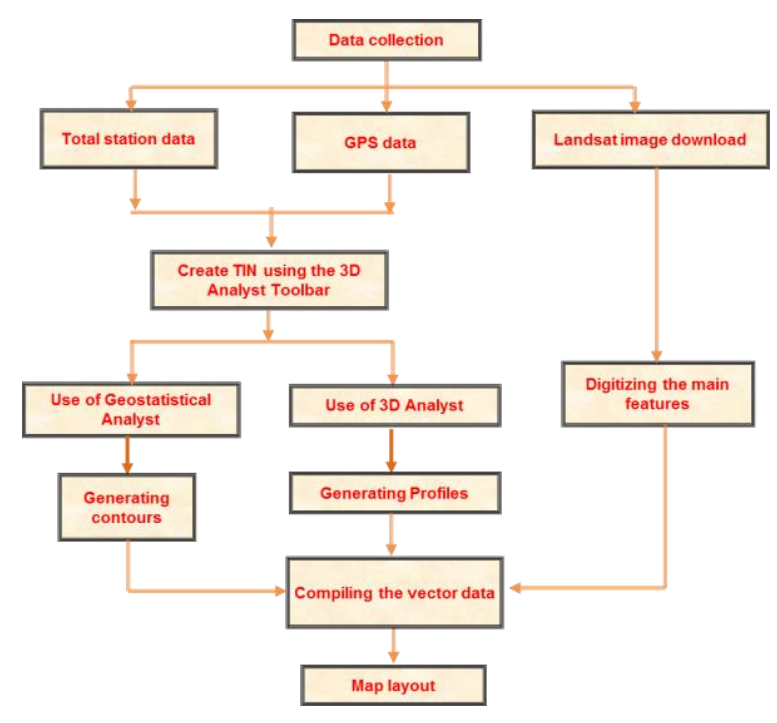

Fig.4. Data processing flow chart

\section{RESULTS AND DISCUSSIONS}

As mentioned in the description of the study area, its extent in the north-south direction is about $49 \mathrm{Km}$. The study area generally slopes longitudinally in the south-north direction and transversally in the west-east direction). Figure 5 has been simplified by removing some layers so as to facilitate its interpretation. It mainly shows the locations of the 3 pump stations (PS1, PS2, and PS3), and the routes of the four canals which are proposed based on the slope and the locations of the farm that are to be irrigated, as follows:

1. Route of the canal from PS1( $x=450,319.9$, $y=1,751,115.5)$ to point $(x=449,478.7$, $y=1,751,433.6)$ at the beginning of the main canal almost corresponding to PS1. The length of this canal is 866 meter.

2. Route of the canal from PS2( $x=452425.2$, $y=1,770,098.8)$ to point $(x=450,447.2$, $y=1,770,307.5)$ along the main canal almost corresponding to PS2. The length of this canal 1,982 meter.

3. Route of the canal from $\operatorname{PS} 3(x=456$, 303.3, $y=1,792,174.2) \quad$ to point $(x=454,812.0, y=1,792,284.4)$ along the main canal almost corresponding to PS3. This canal is 1,823 meter long.

4. Route of the main canal that begins at point $\quad(x=449,478.7, \quad y=1,751,433.6)$, passes through point $(\mathrm{x}=450,447.2$, $y=1,770,307.5)$, and through point $(\mathrm{x}=454,812.0, \mathrm{y}=1,792,284.4)$, and ends at point $(x=457,436.0, y=1,799,220.7)$. This main canal is approx. $49.12 \mathrm{Km}$ long.

All the above measurements are according to the spatial reference of the maps which is the Universal Transverse Mercator projection (i.e. the unit is the meter).

Although Figure 5 shows the entire project area (49 Km long) in an A0 paper map at a scale of $1: 50,000$, but it may be not very clear, therefore the project area was divided into four sections to enable showing each section in an A2 paper map at a scale of 1:25,000.

Thus, Figure 6 shows section (1) which includes the pump station No. (1), canal from 
PS1 to the beginning of the main canal, and approximately $13.232 \mathrm{Km}$ of the main canal span.

Figure 7 shows the branch canal from PS2 to the main canal in addition to an approximate length of $13.61 \mathrm{Km}$ of the main canal.

Figure 8 shows an approximate length of $13.847 \mathrm{Km}$ of the main canal, there is no pump station in this section.

Figure 9 shows the branch canal from PS3 to the main canal in addition to the remaining length of the main canal up to its end which is an approximate length of $14.576 \mathrm{Km}$.

The selection of the routes of the 3 branch canals and the main canal mainly depended on the slope of the terrain, which was studied using several profiles. The profiles of the finally selected routes are shown in the figures [10-15].

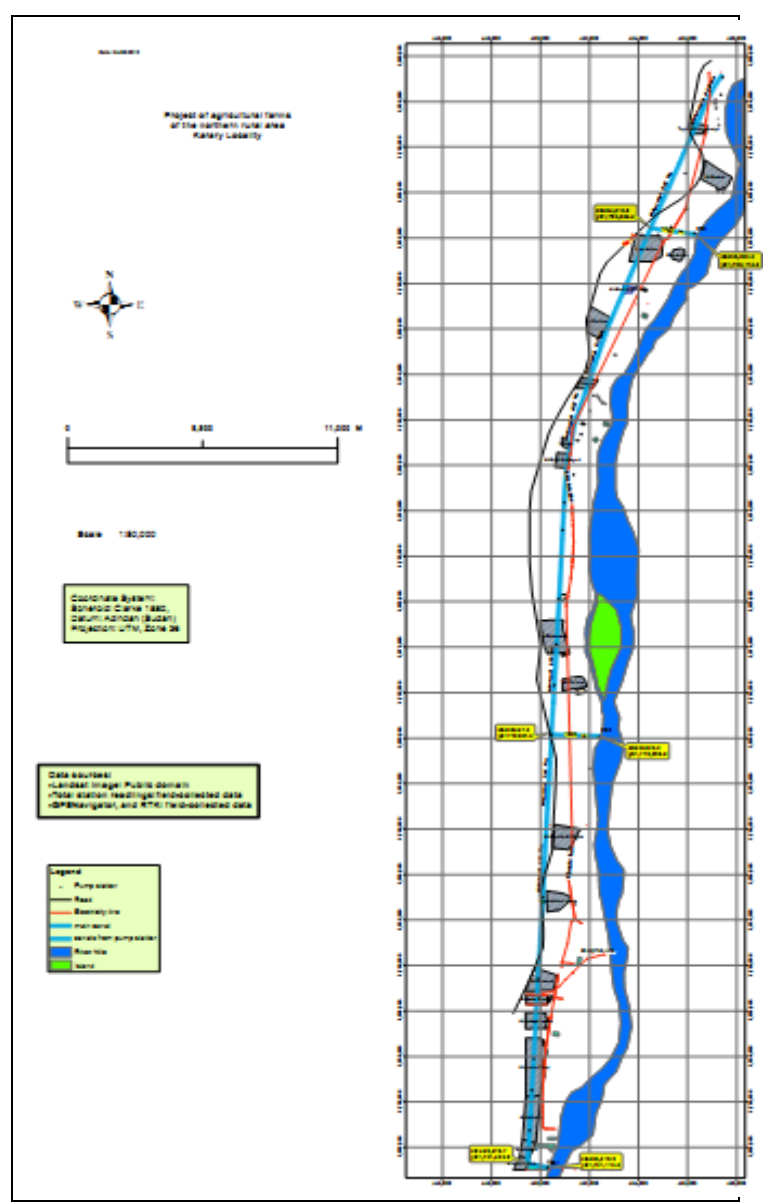

Fig.5. A0 map of the study area

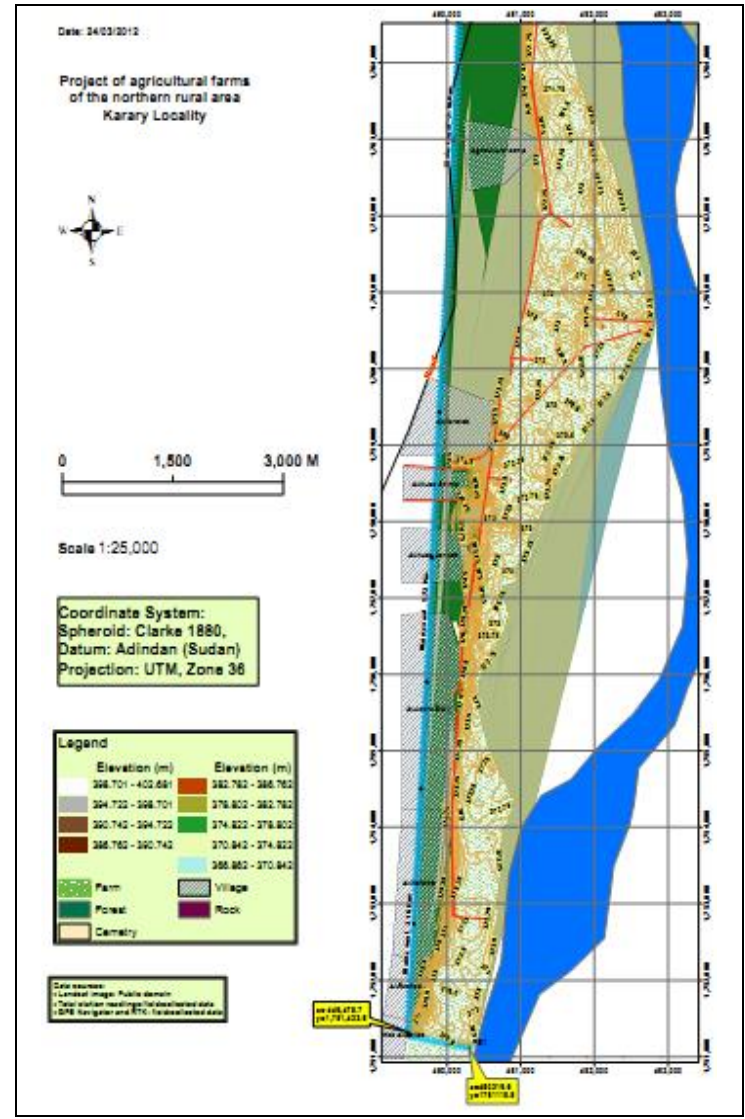

Fig.6. A2 map, the branch canal from PS1 to the main canal

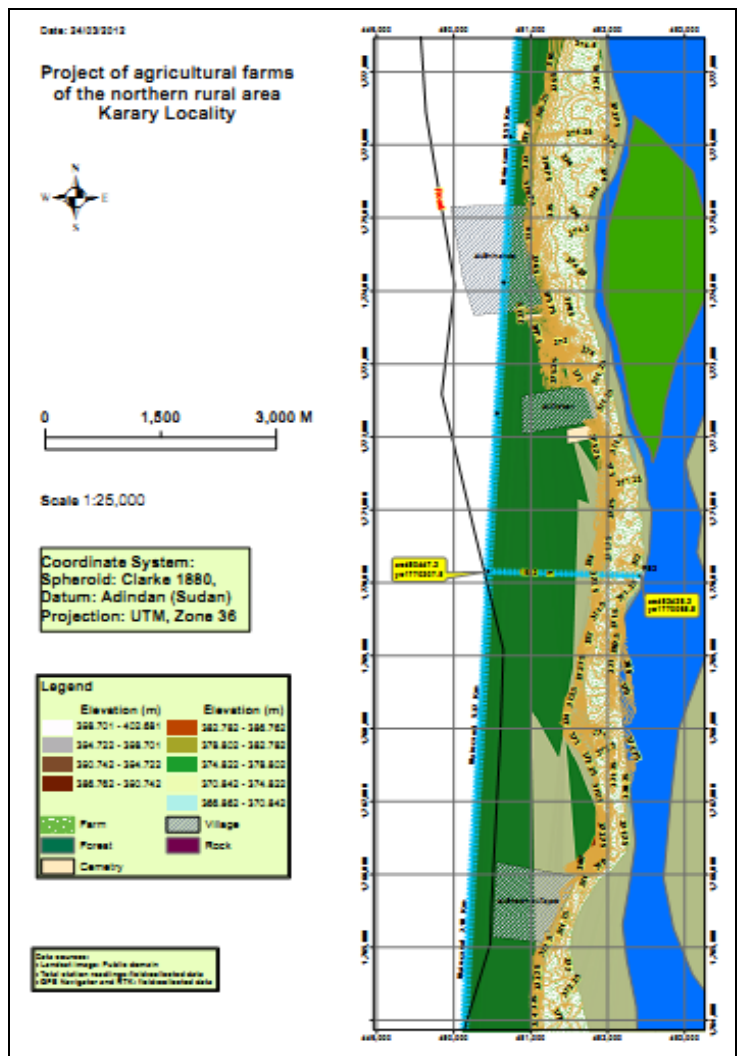

Fig.7. A2 map, the branch canal from PS2 to the main canal 


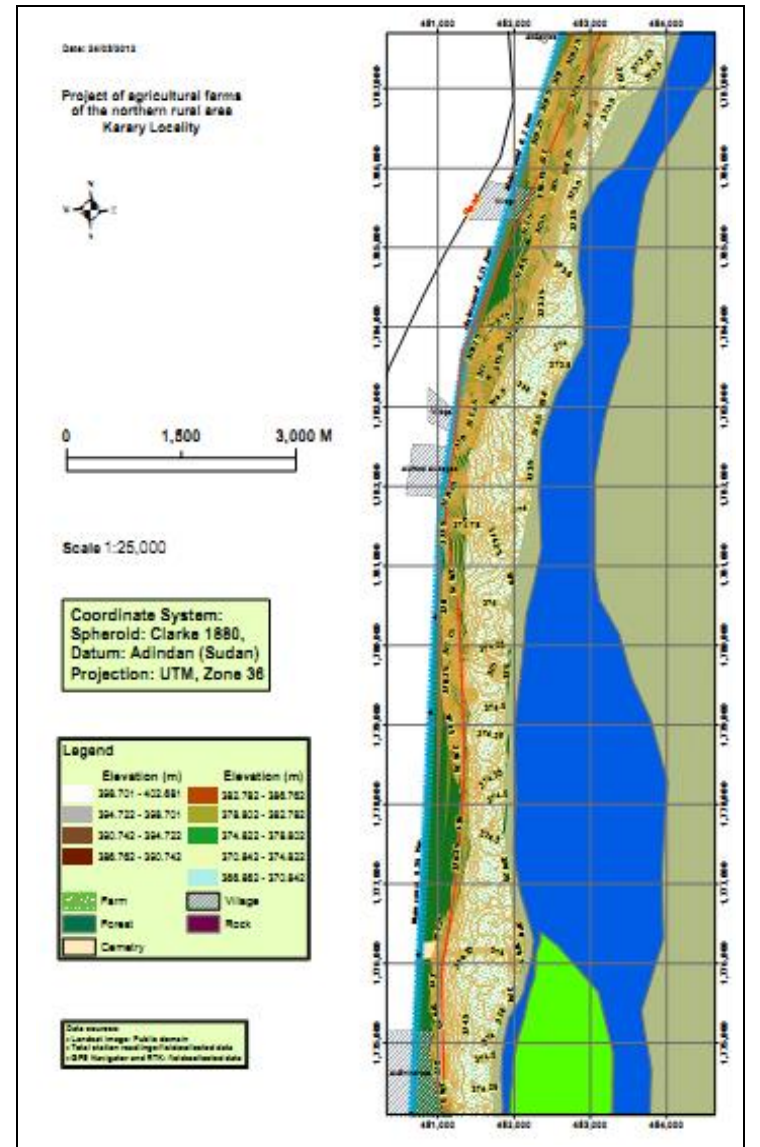

Fig.8. A2 map, the main canal between PS2 and PS3

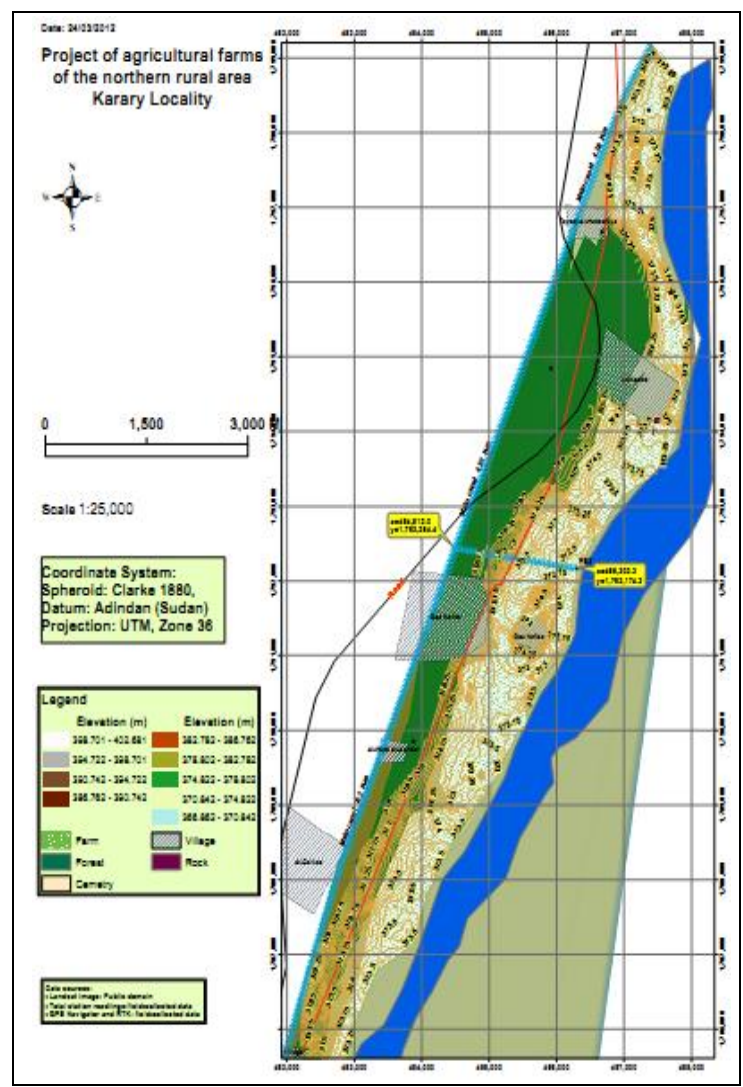

Fig.9. A2 map, the last part of the main canal

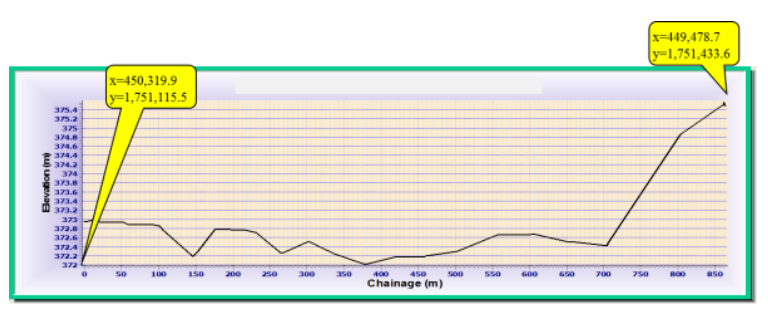

Fig.10. Profile of the branch canal from PS1 to the main canal

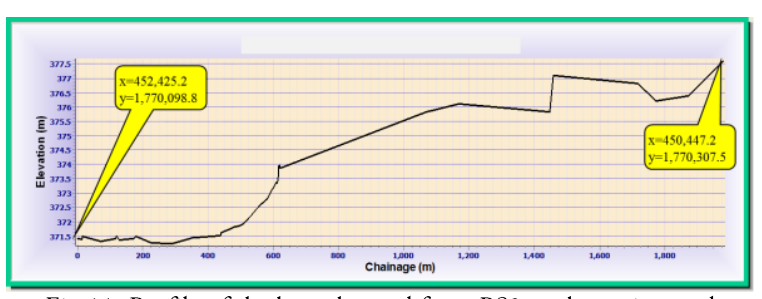

Fig.11. Profile of the branch canal from PS2 to the main canal

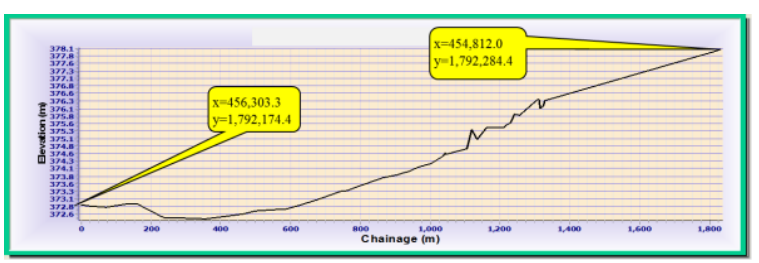

Fig.12. Profile of the branch canal from PS3 to the main canal

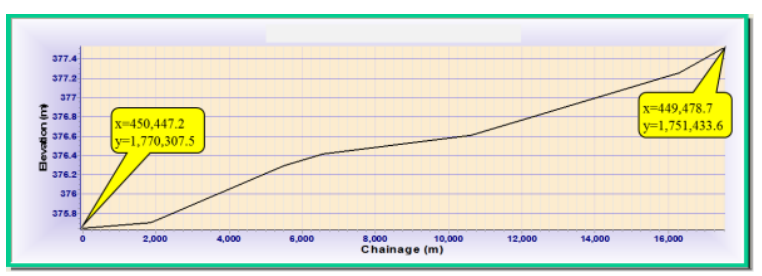

Fig.13. Profile of the main canal from PS1 to PS2

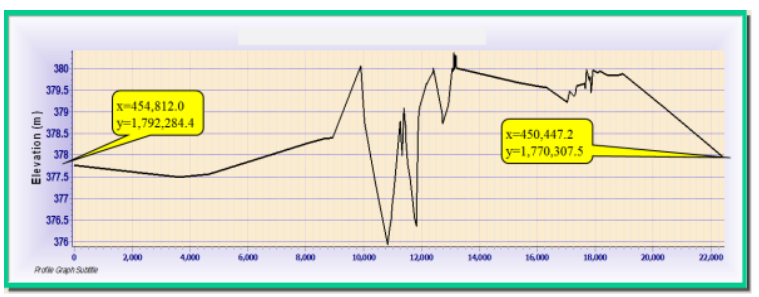

Fig.14. Profile of the main canal from PS2 to PS3

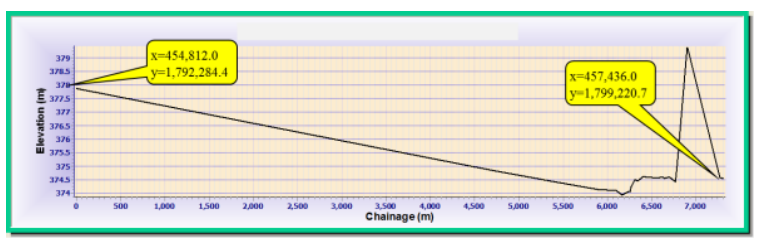

Fig.15. Profile of the main canal from PS3 to the end of the canal

Based on the area of the project which is to be irrigated, the slope of the proposed branch and main canals and with consultation with other specialized professionals, the initial proposal is to establish 3 pump stations: Each 
pump station includes 3 pumps ( 1 is standby and 2 for operation). The capacity of each one is $1.3 \mathrm{~m} \mathrm{~m} / \mathrm{sec}$. therefore; the operational capacity of each station is $2.6 \mathrm{~m}^{3} / \mathrm{sec}$. (2 pumps). The total capacity of the 3 operational pump stations is $2.6 \times 3=7.8$ $\mathrm{m}^{3} / \mathrm{sec}$.

The old system is composed of about 1,280 small pumps with different capacities. The capacity of each pump (based on the size of the irrigated area) ranges from 20 to $30 \mathrm{~m}^{3} / \mathrm{hr}$. These maps were produced - mainly, from total station readings, of which accuracy is within few centimeters, therefore the produced maps are considered accurate enough for the purpose of designing the canals.

Table 2 presents a comparison between the proposed and the existing schemes.

TABLE 2: COMPARISON BETWEEN THE PROPOSED AND EXISTING IRRIGATION SCHEMES

\begin{tabular}{|c|c|c|c|}
\hline $\begin{array}{c}\text { Irrigation } \\
\text { scheme }\end{array}$ & $\begin{array}{c}\text { Total No. of } \\
\text { pumps }\end{array}$ & $\begin{array}{c}\text { Negative } \\
\text { Environmental } \\
\text { Impacts }\end{array}$ & Water supply \\
\hline Proposed & $\begin{array}{c}\text { Large (6 for } \\
\text { operation, and } \\
3 \text { standby) }\end{array}$ & minimum & $\begin{array}{c}\text { Sufficient, } \\
\text { Constant, and } \\
\text { Cheep }\end{array}$ \\
\hline Existing & Small 1,280 & maximum & $\begin{array}{c}\text { Not sufficient, } \\
\text { Not constant, } \\
\text { and } \\
\text { Expensive }\end{array}$ \\
\hline
\end{tabular}

The output from the effort made was the required topographic data - for designing the irrigation system of the project- represented in the topography (contours), and all the existing features in the project area, including - but are not limited to - villages, valleys, pipe lines, power lines, grave yards,...etc). This provided the basic topographic data required for the preparation of the design of the proposed modern irrigation scheme, including proposed routes the irrigation canals and the proposed locations of the pump stations, and irrigation layouts; but the remaining tasks of preparing the bills of quantities and cost estimates, and design of irrigation system infrastructure are beyond the scope of this paper because they should take into account other irrigationrelated parameters and they will be dealt with in other stage by specialized multidisciplinary teams.

\section{CONCLUSION}

Effective agronomic practices are essential components of irrigated systems. Management of the soil fertility, cropping selection and rotation, and pest control may make as much incremental difference in yield as the irrigation water itself. Irrigation implies drainage, soil reclamation, and erosion control. When any of these factors are ignored through either a lack of understanding or planning, agricultural productivity will decline. History is absolutely certain on this point; therefore, it is imperative that multidisciplinary team has to participate in the design of the required irrigation system.

The contribution of the authors of this research paper clearly revealed the very important role the space technology data can play in providing the basic topographical data required for the establishment of a costeffective, environmentally friendly irrigation scheme that reduces the irrigation cost and effort, and accordingly increases productivity, reduces the poverty level and, hence improves the standards of living in the area. The integration of the GIS facilities with these integrated data is an excellent addition to the important role of the space technology data. These facilities present the output of the contribution in the form of dynamic maps accompanied by attribute tables of the different layers of the data, beside the static maps. This data is very useful for planning and conducting the detailed engineering activities to be carried out in the future for the 
implementation of the proposed irrigation scheme in the project area.

\section{RECOMMENDATIONS}

Finally, the authors set forth the following recommendations:

1. Sudan has to place much emphasis on developing the existing agricultural schemes and initiating new ones, so as to bridge the gap, in its economy, caused by the secession of South Sudan, taking about $75 \%$ of petroleum production.

2. Using the open source space technology data for the preliminary studies of such projects shall be adopted.

3. Such projects of irrigation should be carefully studied and designed, since they represent the corner stone with respect to the success of the agricultural projects, because many influencing variables should be taken into account.

4. The use of clean power supply sources for irrigation (such as electric power supply versus petroleum) should be adopted, as far as possible.

\section{REFERENCES}

[1] Elbashir, A., et al., Sudan Poverty Reduction \& Programs in Agriculture, Report Prepared for the Food and Agriculture Organization (FAO) in Khartoum,2004

http://scholar.google.com/scholar?q=Elbashir+et+ al.,+2004,+Sudan+Poverty+Reduction+\%26+Pro grams + in + Agriculture\&hl $=a r \& a s \_s d t=0 \&$ as_vis= 1\&oi=scholart\&sa=X\&ei=Dc8LU72xF4P8ywO4 0oCoAw\&ved=0CCUQgQMwAA

[2] GlobalEDGE, Sudan Economy, Global Insights, 2012

[3] UNP report, Wednesday, July 7, 2004, http://www.fao.org/nr/water/docs/wwf5/b_adg_p anel_finance/muellernote3.doc

[4] Eltoum, Y., 2008, Evaluation of the Factors Affecting the Production and Marketing of Tomato Crop In Khartoum State, Sudan, http://etd2.uofk.edu/view_etd.php?etd_details=2 67 


\title{
إنتاج البيانات الطبوغر افية المطلوبة لنظام ري فعًالٍ باستخدام تكنولوجيا الفضاء دراسة حالة: المناطق الريفيةّة بشمَال أمدرمان
}

\author{
جار النبي إبر اهيم محمد1، يحيى حسن الطيب2 \\ قسم المساحة، كلبة الهندسة، جامعة الخرطوم، السودان1

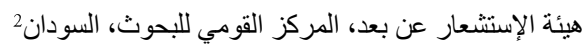

(الملخص:

نظراً إلى الآثار البيئية السالبة المتنامية على نطاق العالم ومستويات المعيشة المتدهورة في السودان، فإنّ هذا البحث تسلط الضوء على مساهمة الكاتبين في مشروعٍ زراعي يهدف إلى المشاركة في إيجاد حلولٍ للمشاكل السائدة في منطقة الدراسة. تقع منطقة الدراسة (التي بستغلها الفلاحون المحليون) شمال مدينة أمدرمان على

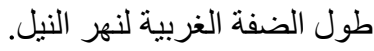

الهذف الرئيسي للمشروع ككل هو تأسيس نظام ريٍٍ يوفر إمداد مياهٍ بتكاليف قليلةٍ وبكمياتٍ كافيةٍ وعلى نحٍِ مستمرٍ من أجل تقليل تكاليف الري و المجهود الذي ييذل في عملية الري ومن أجل زيادة الإنتاجية مما يؤدي إلى تخفيض مستوى الفقر وتحسين مستويات المعيثة.

إنّ مساهمة الكاتبين في هذا المشروع تتمثل في توفير المعلومات الطبوغر افية الأساسية التي تعتبر عاملاً حاسماً لتصميم نظام الري المقترح. لقد نم الحصول على البيانات التي تم إستخدامها (من أجل إنتاج المعلومات الطبوغرافية) عن طريق تكنولوجيا الفضاء مثل قراءات نظام تحديد المواقع على سطح الكرة الأرضية Positioning System Global (بجهاز الإستشعار "الر اسم الخطي المحن +") إضافةً إلى بيانات مساحةٍ أرضيةٍ مقروءةٍ بالموقع باستخدام جهاز المحطة الثشاملة. باستخدام البرنامج التطبيقي Earth Resources Data Analysis System(ERDAS Imagine8.5) نظام تحليل بيانات موارد الأرض( تمت معالجة صور لاندسات ونم تفسير ها واستخلاص معلومات المستوى الأفقي منها. باستخدام البرنامج التطبيقي ArcGIS9.3 (Geostatistical Analyst) أي أدة التحليل الإحصائي للبيانات 
الأرضية تمت معالجة قراءات نظام تحديد المواقع على سطح الكرة الأرضية وقر اءات المحطة الثاملة للحصول على المعلومات اللازمة عن تضاريس الأرض (خطوط الكنتور وتصنيف الإرتفاعات. نتيجةً للمجهود الذي بذله الكاتبان إتضحت - بجلاءٍ ـ أهية دور تكنولوجيا الفضاء لإجر اء الدراسات التي تساعد على تصميم المشاريع التي تؤدي إلى تقليل الآثار البيئية السالبة وتحسين مستويات المعيشة في منطقة المشروع. إنّ تكامل وظائف البرنامج التطبيقي لنظام المعلومات الجغر افية مع هذه البيانات يمثل إضافةً ممتازةً، حيث يؤدي إلى تسهيل عرض النتائج في شكل خر ائط حركيةٍ مصحوبةً بجداول وصفيةٍ للطبقات المختلفة إضافةً إلى الخر ائط الساكنة. إنّ هذه الطبقات مفيدة للغاية لتصميم النشاطات الهندية التفصيلية المطلوبة لتصميم نظام

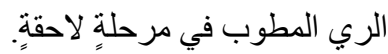

